\title{
Determination of Distribution of Diffusing Capacity in Relation to Blood Flow in the Human Lung*
}

\author{
Richard W. Hyde, † Richard Rynes, $\ddagger$ Gordon G. Power,§ and Jean Nairn\| \\ WITH THE TECHNICAL ASSISTANCE OF PAUL MOYER \\ (From the Department of Physiology, Graduate Division, and the Department of Medicine, \\ University of Pennsylvania, Philadelphia, Pa.)
}

Summary. A method for appraising the distribution of diffusing capacity of the lungs $\left(D_{L}\right)$ in relationship to pulmonary capillary blood flow ( $\dot{Q} \mathrm{c}$ ) in normal human subjects was derived from measurements of oxygen diffusing capacity $\left(\mathrm{DL}_{\mathrm{O}_{2}}\right)$ and carbon monoxide diffusing capacity $\left(\mathrm{DL}_{\mathrm{CO}}\right)$ performed during breath holding. This method utilizes the fact that the observed $\mathrm{DL}_{\mathrm{O}_{2}}$ is considerably reduced in value if uneven distribution of DL with respect to $\dot{Q} c$ (uneven DL/ $\dot{Q} c$ ) is present. In contrast, $\mathrm{DL}_{\mathrm{CO}}$ is barely affected by uneven $\mathrm{DL} / \dot{\mathrm{Q}} \mathrm{c}$, and from its measured value one can calculate the value $\mathrm{DL}_{\mathrm{O}_{2}}$ would have if no uneven $\mathrm{DL} / \dot{Q}_{\mathrm{C}}$ were present (true $\mathrm{DL}_{\mathrm{O}_{2}}$ ). Once observed $\mathrm{DL}_{\mathrm{O}_{2}}$ and true $\mathrm{DL}_{\mathrm{O}_{2}}$ are known, the degree of uneven $\mathrm{DL}_{\mathrm{L}} / \mathrm{Q}_{\mathrm{c}}$ in the lung can be calculated.

In five normal, resting, sitting subjects average values for true $\mathrm{DL}_{\mathrm{O} 2}$ were 57 $\mathrm{ml}$ per (minute $\times \mathrm{mm} \mathrm{Hg}$ ), and the directly measured $\mathrm{DL}_{\mathrm{O}_{2}}$ was $33 \mathrm{ml}$ per (minute $\times \mathrm{mm} \mathrm{Hg}$ ). These values could be explained if one-half of total $\dot{Q} \mathrm{c}$ were distributed to approximately $15 \%$ of total DL.

These measurements did not permit the determination of the alveolar to end capillary $\mathrm{O}_{2}$ gradient, but calculations demonstrate that an important factor in determining its size may be the pattern of uneven DL/Q $\mathrm{c}$ present in the lungs. Estimations of the alveolar-end capillary $\mathrm{O}_{2}$ gradient from measurements of $\mathrm{DLCO}_{\mathrm{CO}}$ or $\mathrm{DL}_{\mathrm{O}_{2}}$ that do not take into account uneven $\mathrm{DL} / \mathrm{Q} \mathrm{c}$ may underestimate its size.

\section{Introduction}

Although the distribution of ventilation with respect to perfusion in the lungs has been extensively investigated, little attention has been given to the distribution of diffusing capacity in

* Submitted for publication June 29, 1966; accepted December 1, 1966.

This work was supported in part by U. S. Public Health Service grant HE 10324-01 and by a grant from the Life Insurance Medical Research Fund.

$\dagger$ Address requests for reprints to Dr. Richard W. Hyde, Dept. of Physiology, Graduate Division, University of Pennsylvania, Philadelphia, Pa. 19104.

Daland Fellow of the American Philosophical Society.

$\ddagger$ Present address: Dept. of Medicine, University of Michigan Medical School, Ann Arbor, Mich.

$\S$ Postdoctoral research fellow, National Institutes of Health.

II Isaac Ott Research Fellow and Fellow of the William McCann Research Trust.

Present address: Institute of Diseases of the Chest, Brompton, London, S.W.3, England. relation to blood flow (1-4). Recently a breathholding method for the determination of $\mathrm{DL}_{\mathrm{O}_{2}}$ has been developed that permits the simultaneous measurement of $\mathrm{DL}_{\mathrm{O}_{2}}$ and $\mathrm{DL}_{\mathrm{CO}}$ (5). The numerical value of $\mathrm{DL}_{\mathrm{O}_{2}}$ was found on a theoretical basis to be quite sensitive to uneven distribution of diffusing capacity with respect to blood flow (uneven DL/Q்c), whereas $\mathrm{DL}_{\mathrm{CO}}$ was relatively insensitive. By comparing the numerical values of $\mathrm{DL}_{\mathrm{O}_{2}}$ and $\mathrm{DL}_{\mathrm{CO}}$, we can evaluate the degree of uneven DL/Q́c in the lungs. The present work uses this approach to study the diffusion-blood flow relationships in the lungs of five normal resting subjects.

\footnotetext{
Methods

Theory

Both steady state and breath-holding methods for measuring $\mathrm{O}_{2}$ diffusing capacity of the lungs require the assumptions of even distribution of diffusing capacity (DL),
} 


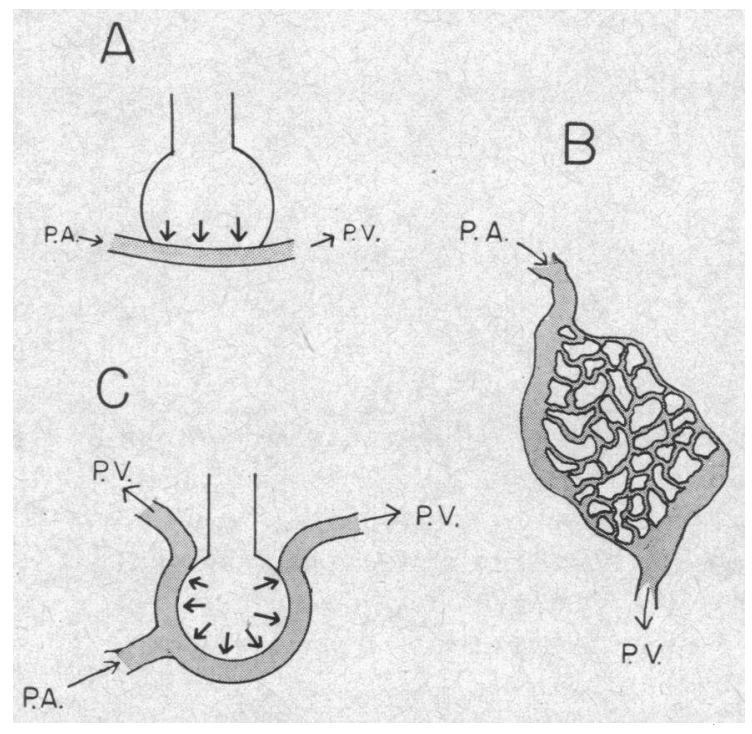

Fig. 1. Diagrams OF THE PULMONARY CAPILlaRY BED. Diagram A illustrates the model of the lung and its pulmonary capillary bed that must be assumed for the determination of oxygen diffusing capacity $\left(\mathrm{DL}_{\mathrm{O}_{2}}\right)$ by either the breath-holding method with ${ }^{34} \mathrm{O}_{2}$ or by the steady state method. Diffusing capacity, capillary blood flow, Q̀c, lung volume, and ventilation are assumed to be distributed evenly. This assumption makes the capillary transit time (TL) from the pulmonary arterioles (labeled P.A.) to the pulmonary veins (labeled P.V.) constant and the end capillary oxygen pressure $\left(\mathrm{Po}_{2}\right.$ or $\left.\mathrm{P}^{34} \mathrm{O}_{2}\right)$ constant throughout the lung. Diagram B, adapted from Von Hayek (9), represents a more anatomically correct view of the pulmonary capillary bed, and since it is likely that some of the blood travels from P.A. to P.V. at different speeds, uneven distribution of diffusing capacity to capillary blood flow (uneven DL/Q்c) is a distinct possibility. Diagram $C$ is the lung model used in this paper. Each alveolus is considered to be perfused by two capillaries that may have different lengths and receive different amounts of $\dot{Q}$. Unlike diagram $\mathrm{A}$, in this model uneven $\mathrm{DL} / \dot{\mathrm{Q}} \mathrm{c}$ may be present depending on the values chosen for the length of the two capillaries and their respective $\dot{Q} c$.

pulmonary capillary blood flow ( $\dot{Q} \mathrm{c}$ ), and pulmonary capillary blood volume $(\mathrm{Vc})$ along the capillaries. These assumptions are made in order to have a constant alveolarend capillary gradient for $\mathrm{O}_{2}(6)$ or $\mathrm{O}_{2}$ isotope throughout the lungs (5). A number of anatomical observations in vivo and in vitro indicate that the pulmonary capillary bed is in fact a meshwork of capillaries along the wall of each alveolus $(7,8)$. It is therefore likely that as blood moves from the pulmonary arterioles to the pulmonary veins, some capillary pathways will be longer than others. In comparison to the shorter ones, these long capillaries have a greater surface area and thereby a larger DL. If blood flow is not distributed to the different capillary pathways in proportion to their respective lengths (7), uneven distribution of DL with respect to Q́c will result (see Figure 1).
Since each alveolus has many capillary pathways of varying length, there is the possibility of a large number of different DL/Q்c compartments within each gas exchange unit.

An analysis that takes into consideration many DL/Q்c compartments, although probably more representative of the lungs in vivo, makes calculations extremely tedious. We, therefore, assumed a two compartment system representing two capillaries of different length coursing along the alveolar wall (see Figure 1C). In addition, we assumed that all the capillaries have the same cross-sectional area and capillary wall thickness (even distribution of diffusing capacity with respect to pulmonary capillary blood volume). The DL/Q́c ratio of different capillary pathways can then be expressed in terms of capillary transit time $(\mathrm{TL}) .^{1}$ For instance, pathways with a low DL/Q்c ratio will have a relatively short $T_{L}$, and capillaries with a high DL/Q்c ratio will have a relatively long $T_{L}$. It should be noted that this model places uneven DL/Q்c within each gas exchange unit rather than in gross regions of the lungs such as lobes or segments.

Effect of uneven DL/Q்c on $\mathrm{DL}_{\mathrm{O}_{2}}$. The measurement of $\mathrm{DL}_{\mathrm{O}_{2}}$ with ${ }^{34} \mathrm{O}_{2}$ requires breath holding after the inspiration of a gas mixture enriched with the stable $\mathrm{O}_{2}$ isotope of mass $34\left({ }^{34} \mathrm{O}_{2}\right)$. The partial pressure of ${ }^{34} \mathrm{O}_{2}\left(\mathrm{P}^{34} \mathrm{O}_{2}\right)$ is very low in the blood at the start of the capillary and then progressively increases until at the end of the capillary its mean value determined experimentally is approximately $70 \%$ of the alveolar $\mathrm{P}^{34} \mathrm{O}_{2}$ (5). However, if uneven $\mathrm{DL} / \mathrm{Q}_{\mathrm{c}} \mathrm{c}$ is present, in those capillaries with a long $T_{L}$ (or high DL/Q்c), the alveolar $\mathrm{P}^{34} \mathrm{O}_{2}$ and capillary $\mathrm{P}^{34} \mathrm{O}_{2}$ will have sufficient time to come almost into equilibrium before reaching the end of the capillary. Once equilibrium is approached, minimal ${ }^{34} \mathrm{O}_{2}$ uptake takes place along that portion of the capillary. Because ${ }^{34} \mathrm{O}_{2}$ uptake is slight at the end of those capillaries with a long $\mathrm{TL}_{L}$, the ${ }^{34} \mathrm{O}_{2}$ uptake for any given alveolar $\mathrm{P}^{34} \mathrm{O}_{2}$ is reduced. This reduction results in a decrease in calculated $\mathrm{DL}_{\mathrm{O}_{2}}$. Therefore if uneven $\mathrm{DL} / \dot{\mathrm{Q}} \mathrm{c}$ is present, the observed diffusing capacity will be lower than if $\mathrm{DL} / \dot{Q}_{\mathrm{c}}$ is evenly distributed (see Figure 2).

Effect of uneven DL/Q்c on DLco. In the determination of DLco alveolar CO is so low (approximately $1.5 \mathrm{~mm} \mathrm{Hg}$ ) that only a small amount of $\mathrm{CO}$ diffuses into the blood in the pulmonary capillaries. Because the $\mathrm{CO}$ entering the capillary blood is such a small fraction of its total capacity for $\mathrm{CO}$, unlike the case for ${ }^{34} \mathrm{O}_{2}$ described above, there is little change in capillary Pco during breath holding. Even if in some of the capillaries $T_{L}$ is considerably longer than the mean $T_{L}$, there is only a slight increase in capillary

1 The assumption of even distribution of diffusing capacity with respect to $\mathrm{Vc}$ is not essential, but seems reasonable on the basis of both anatomical and physiological considerations $(8,10)$. If this assumption is granted, Vc is proportional to $D_{L}$, and the $T_{L}$ for any capillary or group of capillaries can be calculated from the following relationship: $T_{L}=V c / \dot{Q} c$. This equation permits the analysis of uneven DL/Q $\mathrm{C}$ in terms of $T_{L}$, which is synonymous with the terms alveolar-capillary contact time (11) or time along the capillary (12) used by others. 
Pco as blood moves along the pulmonary capillaries. Because there is little increase in capillary Pco, total CO uptake and calculated DL $\mathrm{LO}_{\text {co }}$ are relatively insensitive to uneven $\mathrm{DL} / \mathrm{Q} c$ compared to $\mathrm{DL}_{\mathrm{O}_{2}}$. For instance, if in $80 \%$ of the capillary bed the transit time increased from a normal value of about 0.8 second to 5 seconds, the end capillary Pco would only rise to about $0.14 \mathrm{~mm} \mathrm{Hg}$, which is less than $10 \%$ of the alveolar Pco. ${ }^{2}$ Such an increase in end

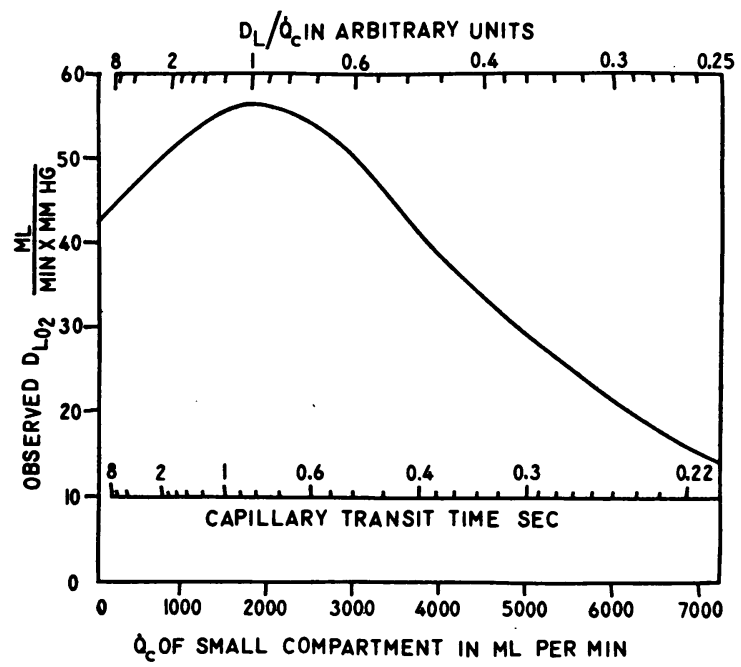

Fig. 2. Change in measured $\mathrm{Dl}_{\mathrm{O}_{2}}$ (observed $\mathrm{DL}_{\mathrm{O}_{2}}$ ) PRODUCED BY DIFFERENT AMOUNTS OF Q C GOING THROUGH $25 \%$ OF THE LUNG'S DIFFUSING CAPACITY. A hypothetical lung is considered to have two compartments containing $25 \%$ and $75 \%$ of the total diffusing capacity. Total or true $\mathrm{DL}_{\mathrm{O}_{2}}$ is given a value of $57 \mathrm{ml}$ per (minute $\times \mathrm{mm} \mathrm{Hg}$ ), Q́c a value of 7,200 $\mathrm{ml}$ per minute, and pulmonary capillary blood volume (Vc) a value of $100 \mathrm{ml}$. Observed $\mathrm{DL}_{\mathrm{O}_{2}}$, the value of $\mathrm{DL}_{\mathrm{O}_{2}}$ that would be determined by using the breath-holding isotope method (5), according to the mathematical methods derived in the text will only equal true $\mathrm{DL}_{\mathrm{O}_{2}}$ when the ratio of diffusing capacity to $\dot{Q} \mathrm{c}$ of each compartment is 57 to 7,200 (even DL/Q்c and indicated by 1 arbitrary unit on the upper horizontal axis). If $\mathrm{DL} / \dot{\mathrm{Q}} \mathrm{c}$ is uneven $(25 \%$ of the diffusing capacity receives either more or less than $25 \%$ of total $\dot{Q}$ ), observed $\mathrm{DL}_{\mathrm{O}_{2}}$ will be less than its maximal value of $57 \mathrm{ml}$ per (minute $\times \mathrm{mm} \mathrm{Hg}$ ). Note that the greater the abnormality in $\mathrm{DL} / \dot{\mathrm{Q}} \mathrm{c}$, the greater is the fall in observed $\mathrm{DL}_{\mathrm{O}_{2}}$. Capillary transit time for the small compartment was calculated by the method described in the first footnote.

${ }_{2}^{2}$ The end capillary Pco of $0.14 \mathrm{~mm} \mathrm{Hg}$ was obtained by the following calculation: In a subject with a $\mathrm{DL}_{\mathrm{Co}}$ of 35 $\mathrm{ml}$ per (minute $\times \mathrm{mm} \mathrm{Hg}$ ), at an average alveolar Pco of $1.5 \mathrm{~mm} \mathrm{Hg}$ the amount of CO entering $80 \%$ of the capillary bed in 5 seconds would be $0.8 \times 35 \times 1.5 \times(5 / 60)$ or $3.5 \mathrm{ml}$. If the $\mathrm{Vc}$ were $100 \mathrm{ml}$ and the hemoglobin concentration $15 \mathrm{~g}$ per $100 \mathrm{ml}$, then the total $\mathrm{CO}$ capacity of the blood in $80 \%$ of $\mathrm{Vc}$ would be $0.8 \times 100 \times 1.34 \times(15 /$ 100 ) or $16 \mathrm{ml}$. The per cent carboxyhemoglobin saturation at the end of these capillaries would be $(3.5 / 16) \times 100$

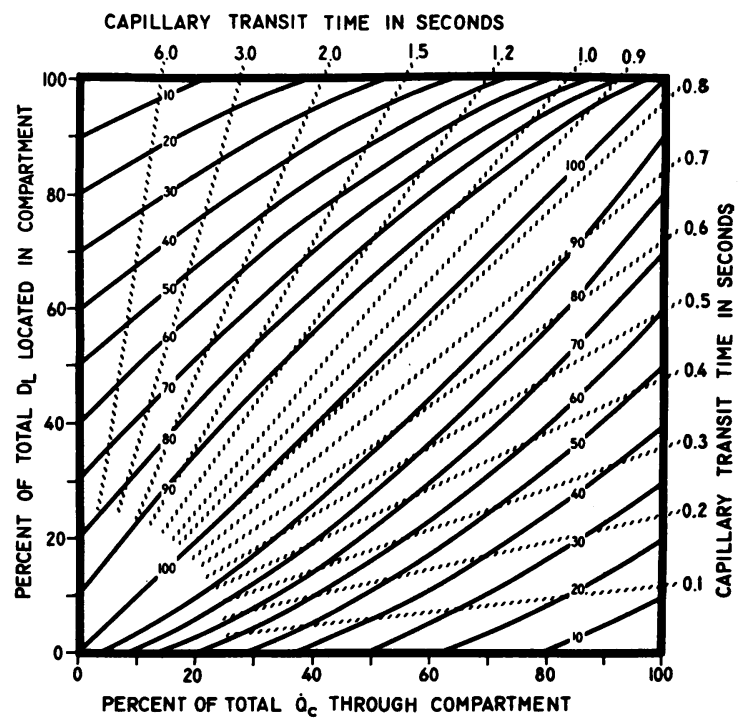

Fig. 3. Graphical solution of Equation 4 in text. This chart permits the determination of the dimensions of DL and $\dot{Q} c$ in a lung with two compartments that might have different values for DL and Q்c. Numerical constants used are representative values for our subjects, namely true $\mathrm{DL}_{\mathrm{O}_{2}}=57 \mathrm{ml}$ per (minute $\times \mathrm{mm} \mathrm{Hg}$ ), total $\dot{\mathrm{Q}} \mathrm{c}$ $=7,200 \mathrm{ml}$ per minute, the Bunsen solubility coefficient for total $\mathrm{O}_{2}$ in blood $\left(\alpha \mathrm{b}_{\mathrm{O}_{2}}\right)=2.5$, and $\mathrm{Vc}=100 \mathrm{ml}$. The diagonal solid slightly curved lines are isopleths of observed $\mathrm{DL}_{\mathrm{O}_{2}}$ as a percentage of true $\mathrm{DL}_{\mathrm{O}_{2}}$. The broken lines are isopleths of $\mathrm{TL}_{\mathrm{L}}$ in seconds. As an example, assume that one compartment contains $20 \%$ of DL and observed $\mathrm{DL}_{\mathrm{O}_{2}}$ is $60 \%$ of true $\mathrm{DL}_{\mathrm{O}_{2}}$. One then reads across from the $20 \%$ point on the upright axis to the diagonal solid line labeled 60. At this point the corresponding point on the horizontal axis is $56 \%$, which is the per cent of the total $\dot{Q} c$ passing through the compartment. Since the interrupted line labeled 0.3 passes through the same point, $\mathrm{T}_{\mathrm{L}}$ for this compartment is 0.3 second. The other compartment must then contain $80 \%$ of DL and $44 \%$ of $\dot{Q} c$, and its $T_{L}$ determined from the chart would be 1.5 seconds. At the present time we have no method of determining which of the solutions lying along the isopleths of observed $\mathrm{DL}_{\mathrm{O}_{2}}$ as a percentage of true $\mathrm{DL}_{\mathrm{O}_{2}}$ represents the correct answer (or answers), and since the lung is most likely composed of a large number of DL-Q்c compartments, a two compartment model can only be a rough approximation of the situation present in vivo.

capillary Pco would result in a fall of $\mathrm{DLCo}_{\mathrm{CO}}$ of less than $5 \%{ }^{3}$ However, with the same increase in $\mathrm{TL}_{2}, \mathrm{DLO}_{2}$ would

or $22 \%$. From the Haldane relationship (13) with a value of 240 for the relative affinity of hemoglobin for $\mathrm{CO}$ as compared with $\mathrm{O}_{2}(\mathrm{M})$ and $120 \mathrm{~mm} \mathrm{Hg}$ for intracapillary $\mathrm{PO}_{2}$, end capillary $\mathrm{PCO}=(120 \times 22) /[(240)(99-22)]$ or $0.14 \mathrm{~mm} \mathrm{Hg}$.

${ }^{3}$ Even though the end capillary Pco is $0.14 \mathrm{~mm} \mathrm{Hg}$ in the capillaries with a $T_{L}$ of 5 seconds, from multiple deter- 
fall to less than one-third of the value it would have if DL/Q்c were evenly distributed. ${ }^{4}$

Determination of value of $\mathrm{DL}_{\mathrm{O}_{2}}$ if $\mathrm{DL}$ and $\dot{\mathrm{Q}} \mathrm{c}$ are evenly distributed (true $\mathrm{DL}_{\mathrm{O}_{2}}$ ). Since uneven $\mathrm{DL} / \dot{\mathrm{Q}} \mathrm{c}$ may decrease the numerical value of $\mathrm{DL}_{\mathrm{O}_{2}}$ measured with ${ }^{34} \mathrm{O}_{2}, \mathrm{DL}_{\mathrm{O}_{2}}$ measured by this technique was called the "observed DL $\mathrm{O}_{2} . "$ The degree of unevenness of DL/Q்c was calculated by determining the difference between the observed $\mathrm{DL}_{\mathrm{O}_{2}}$ and the true $\mathrm{DL}_{\mathrm{O}_{2}}$. By "true $\mathrm{DL}_{\mathrm{O}_{2}}$ " we mean the value of $\mathrm{DL}_{\mathrm{O}_{2}}$ that would be present if diffusing capacity and $\dot{Q} c$ were evenly distributed. Since $D_{L_{C O}}$ is barely affected by uneven $\mathrm{DL} / \dot{\mathrm{Q}} \mathrm{c}$, true $\mathrm{DL}_{\mathrm{O}_{2}}$ was determined indirectly from measurements of the pulmonary capillary blood volume (Vc) and diffusing capacity of the alveolarcapillary membrane for $\mathrm{CO}\left(\mathrm{DM}_{\mathrm{CO}}\right.$ ) calculated by measuring DLco at alveolar $\mathrm{O}_{2}$ tensions of approximately $150 \mathrm{~mm} \mathrm{Hg}$ and $600 \mathrm{~mm} \mathrm{Hg}$ (14). The following formula was then used to calculate true $\mathrm{DL}_{\mathrm{O}_{2}}$ :

$$
\begin{aligned}
\frac{1}{\text { true } \mathrm{DL}_{\mathrm{O}_{2}}}=\frac{1}{\mathrm{DM}_{34 \mathrm{O}_{2}}} & +\frac{1}{(\mathrm{Vc})\left(\theta \mathrm{O}_{2}\right)} \\
& =\frac{1}{(1.19)\left(\mathrm{DM}_{\mathrm{CO}}\right)}+\frac{1}{(\mathrm{Vc})\left(\theta \mathrm{O}_{2}\right)} .
\end{aligned}
$$

The two right-hand terms of the above equation equal, respectively, the resistance to diffusion from the alveolus through the alveolar-capillary membrane into the plasma in the capillaries $\left(1 / \mathrm{DM}_{34} \mathrm{O}_{2}\right)$ and the resistance to diffusion from the plasma into the interior of the red blood cells $\left[1 /\left(\mathrm{Vc} \times \theta_{2}\right)\right]$. Their sum, which is the left-hand term $\left(1 /\right.$ true $\left.\mathrm{DL}_{\mathrm{O}_{2}}\right)$, equals the total resistance to diffusion. $\theta \mathrm{O}_{2}$ is the diffusing capacity of the red blood cell for $\mathrm{O}_{2}$

expressed in milliliters per (minute $\times$ millimeters $\mathrm{Hg}$ $X$ milliliters), and the values reported by Staub, Bishop, and Forster were used (15). $\mathrm{DM}_{\mathrm{O}_{2}}$, the diffusing capacity of the alveolar-capillary membrane for ${ }^{34} \mathrm{O}_{2}$, expressed in milliliters per (minute $\times$ millimeters $\mathrm{Hg}$ ), was considered to be equal to DMco multiplied by 1.19 on the basis of Graham's law of diffusivity of gases. ${ }^{5}$ The derivation of an expression similar to Equation 1 is described by Roughton and Forster (14).

Quantitative analysis of uneven $\mathrm{DL} / \mathrm{Q} c$. Observed $\mathrm{DL}_{\mathrm{O}_{2}}$ is calculated by the following formula, whose derivation is given in detail elsewhere (5):

$$
\text { observed } \mathrm{DL}_{\mathrm{O}_{2}}=\frac{\dot{\mathrm{Q}} \mathrm{c}\left(\alpha \mathrm{b}_{\mathrm{O}_{2}}\right)}{760} \ln \left(\frac{1}{\mathrm{~K}}\right)
$$

where $\dot{Q} c$ is the pulmonary capillary blood flow in milliliters per minute measured by the acetylene breath-holding method (16), and $\alpha b_{\mathrm{O}_{2}}$ is the Bunsen solubility coefficient for total $\mathrm{O}_{2}$ in the blood in milliliters per milliliter per standard atmosphere calculated from the capillary $\mathrm{Po}_{2}$ present during breath holding and the $\mathrm{O}_{2}$ capacity of the subject's blood. $\mathrm{K}$ is a constant and is defined in the following manner :

$$
\mathrm{K}=\frac{\text { alveolar } \mathrm{P}^{34} \mathrm{O}_{2}-\text { end capillary } \mathrm{P}^{34} \mathrm{O}_{2}}{\text { alveolar } \mathrm{P}^{34} \mathrm{O}_{2}-\text { mixed venous } \mathrm{P}^{34} \mathrm{O}_{2}}
$$

$\mathrm{K}$ is determined from the rate of disappearance of ${ }^{34} \mathrm{O}_{2}$ during breath holding and has a numerical value of about 0.3 in normal subjects. If the lung is divided into two compartments with different DL/Q்c ratios such as illustrated in Figure 1C, the relationship between observed $\mathrm{DL}_{\mathrm{O}_{2}}$ and true $\mathrm{DL}_{\mathrm{O}_{2}}$ will be the following :

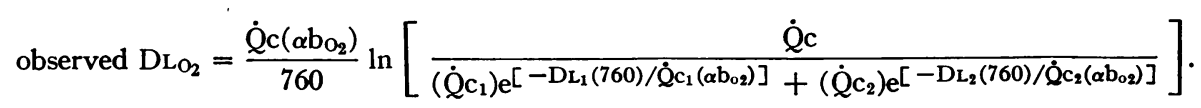

$\dot{Q} c_{1}$ and $\dot{Q} c_{2}$ are the respective blood flows through the two compartments, and their sum equals $\dot{Q} c$. $D L_{1}$ and $\mathrm{DL}_{2}$ are the respective diffusing capacities of the two compartments, and their sum equals true $\mathrm{DL}_{\mathrm{O}_{2}}$. The detailed

minations of the capillary Pco over the 5-second interval, it is apparent that the mean capillary Pco would be less than half this value. Since $C O$ uptake and $D_{\text {co }}$ are determined by the alveolar-mean capillary $\mathrm{CO}$ gradient, the reduction in calculated $\mathrm{DL}_{\mathrm{Co}}$ in this part of the capillary bed would be less than $5 \%$. In addition, in the $20 \%$ of the capillary bed with a short $T_{L}$, the mean capillary Pco would be negligible, so that calculated $\mathrm{DL}_{\mathrm{co}}$ in these capillaries would be unaffected by uneven DL/Q்c.

${ }^{4}$ See Figure 3 for dimensions of $\mathrm{DL}_{\mathrm{O}_{2}}$, Vc, and $\dot{Q} \mathrm{c}$ used. Since $80 \%$ of Vc had a TL of 5 seconds, Q ment could be calculated from the relationship $\dot{Q} c=V c /$ $T_{L}$ and was found to be $14 \%$ of total Q $c$. Since it is assumed that Vc and DL are evenly distributed, a compartment with $80 \%$ of total Vc contains $80 \%$ of total $\mathrm{DL}_{\mathrm{O}_{2}}$. From Figure 3 it is apparent that if one compartment has $80 \%$ of total $\mathrm{DL}_{\mathrm{O}_{2}}$ and $14 \%$ of $\dot{\mathrm{Q}} \mathrm{c}$, the observed $\mathrm{DL}_{\mathrm{O}_{2}}$ is $30 \%$ of the true $\mathrm{DL}_{\mathrm{O}_{2}}$ (vide infra). derivation of Equation 4 is given in the Appendix. Figure 3 is a graphical solution of Equation 4 that permits the determination of the dimensions of the two diffusing capacity-blood flow compartments for any given value of observed $\mathrm{DL}_{\mathrm{O}_{2}}$ expressed as a percentage of true $\mathrm{DL}_{\mathrm{O}_{2}}$. Numerical constants used are given in the legend to the Figure.

\section{Procedures}

Equation 4 was applied in the following manner: Observed $\mathrm{DL}_{\mathrm{O}_{2}}$ and $\dot{Q} \mathrm{c}$ were measured from the rate of disappearance of ${ }^{34} \mathrm{O}_{2}$ and acetylene $\left(\mathrm{C}_{2} \mathrm{H}_{2}\right)$ during breath holding $(5,16)$. The sum of $\mathrm{DL}_{1}$ plus $\mathrm{DL}_{2}$, which by definition equals true $\mathrm{DL}_{\mathrm{O}_{2}}$, was determined by the following steps: First the $\mathrm{DL}_{\mathrm{co}}$ was measured at alveolar $\mathrm{Po}_{2}$ of approximately 150 and $600 \mathrm{~mm} \mathrm{Hg}$, and then the values for $\mathrm{Vc}$

5 According to Graham's law, the diffusivity of two gases through a liquid is proportional to the ratio of their solubilities and inversely proportional to the ratio of the square root of their molecular weights. If the alveolarcapillary membrane is considered to be essentially water, $\mathrm{DM}_{34 \mathrm{O}_{2}}=\mathrm{DM}_{\mathrm{CO}}(0.244 / 0.0185)(28 / 34)=(1.19)\left(\mathrm{DM}_{\mathrm{CO}}\right)$. 
and DMco were calculated (14). These values were then substituted into Equation 1 in order to obtain the value of true $\mathrm{DL}_{\mathrm{O}_{2}}$ for each subject. The term $\mathrm{DL}_{2}$ in Equation 4 can then be eliminated by replacing it with true $\mathrm{DL}_{2}-$ $\mathrm{DL}_{1}$. Likewise since $\dot{\mathrm{Q}} \mathrm{c}_{1}+\dot{\mathrm{Q}} \mathrm{c}_{2}=\dot{\mathrm{Q}} \mathrm{c}, \dot{\mathrm{Q}} \mathrm{c}_{2}$ can be replaced by the term $\dot{Q} c-\dot{Q} c_{1}$. Because two unknown terms remain in Equation 4, namely $D L_{1}$ and $\dot{Q} c_{1}$, these values can be expressed as a locus of possible solutions on a graph. For example, Figure 3 is the graphical solution for Equation 4 in a hypothetical subject with a true $\mathrm{DL}_{\mathrm{O}_{2}}$ of $57 \mathrm{ml}$ per (minute $\times \mathrm{mm} \mathrm{Hg}$ ), Q்c of 7,200 ml per minute, and $\alpha \mathrm{b}_{\mathrm{O}_{2}}$ of $2.5 \mathrm{ml}$ per ml per standard atmosphere. Note that any point on one of the unbroken curved lines of the Figure represents a possible pair of values for $D_{L_{1}}$ and $\dot{Q} c_{1}$ for a particular observed $\mathrm{DL}_{\mathrm{O}_{2}}$ expressed as a percentage of true $\mathrm{DL}_{\mathrm{O}_{2}}$. Because Equation 4 must be solved by a method of trial and error or with a computer, its graphical solution presented in Figure 3 is helpful in estimating the values of $\mathrm{DL}_{1}$ and $\dot{Q}_{1}$ that would satisfy the values of observed $\mathrm{DL}_{\mathrm{O}_{2}}$ and true $\mathrm{DL}_{\mathrm{O}_{2}}$ obtained in our subjects. With the assistance of this Figure, Equation 4 was solved for each subject, and the solutions were then plotted in Figure 4.

\section{Subjects}

Measurements for the determination of uneven DL/Q்c were made in five male laboratory personnel, skilled at respiratory maneuvers, in the sitting position. Values for observed $\mathrm{DL}_{\mathrm{O}_{2}}$ previously reported were used (5). At the time of the measurements no symptoms of respiratory disease were present. Chest $\mathrm{X}$ rays were read as showing no active disease, and vital capacities as well as maximal midexpiratory flow rates were within the normal limits recently published by Bates and Christie (17). Physical characteristics of the subjects are listed in Table I.

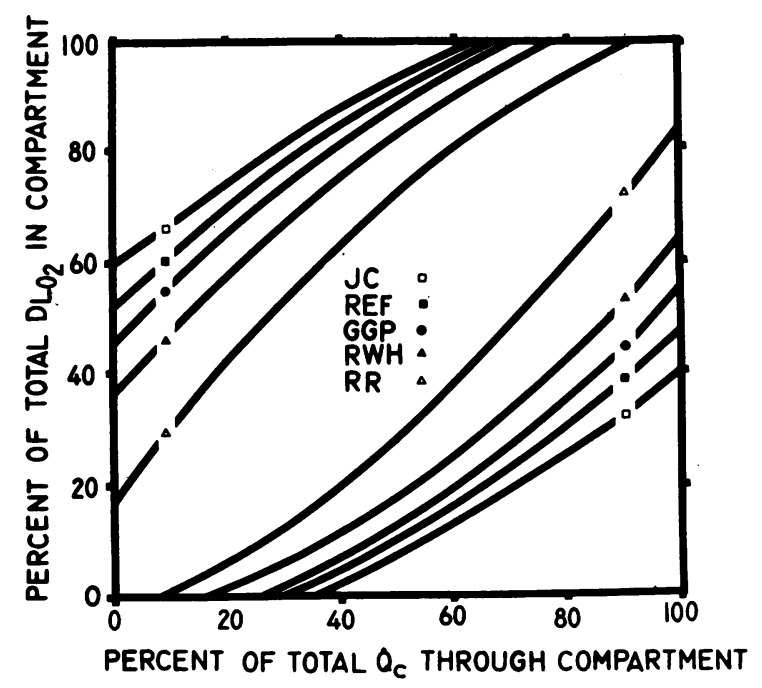

Fig. 4. EXPERIMENTALly DETERMined Distribution of $\mathrm{DL}_{\mathrm{O}_{2}}$ WITH RESPECT To Q̇c. The curved lines represent the patterns of uneven DL/Q்c that would explain the experimental findings for each subject. The two older subjects (JC and REF) have the more uneven DL/Q்c.
TABLE I

Physical characteristics of experimental subjects

\begin{tabular}{lcccc}
\hline \hline Subject & Age & Height & Weight & $\begin{array}{c}\text { Surface } \\
\text { area }\end{array}$ \\
\hline & years & inches & pounds & $m^{2}$ \\
RR & 24 & 72 & 175 & 2.01 \\
GGP & 28 & 73 & 175 & 2.03 \\
RWH & 34 & 71 & 160 & 1.94 \\
REF & 44 & 74 & 170 & 2.02 \\
JC & 46 & 64 & 132 & 1.65 \\
\hline
\end{tabular}

\section{Results}

The data for determining true $\mathrm{DL}_{\mathrm{O}_{2}}$ and observed $\mathrm{DL}_{\mathrm{O}_{2}}$ are listed in Table II. For the five subjects the average value for $\mathrm{DL}_{\mathrm{CO}}$ was $44 \mathrm{ml}$ per (minute $\times \mathrm{mm} \mathrm{Hg}$ ), and observed $\mathrm{DL}_{2}$ measured simultaneously was $33 \mathrm{ml}$ per (minute $\times \mathrm{mm} \mathrm{Hg}$ ). The value for Vc calculated from measurements of $\mathrm{DL}_{\mathrm{CO}}$ at different alveolar $\mathrm{PO}_{2}$ was $104 \mathrm{ml}$, and $\mathrm{DM}_{\mathrm{CO}}$ was $61 \mathrm{ml}$ per (minute $X$ $\mathrm{mm} \mathrm{Hg}$ ). From these figures the value for true $\mathrm{DL}_{\mathrm{O}_{2}}$ for the five subjects was calculated. The average was $57 \mathrm{ml}$ per (minute $\times \mathrm{mm} \mathrm{Hg}$ ), which is considerably greater than the observed $\mathrm{DL}_{\mathrm{O}_{2}}$ of $33 \mathrm{ml}$ per (minute $\times \mathrm{mm} \mathrm{Hg}$ ).

The pattern of uneven DL/Q் for each subject calculated from Equation 4 is plotted in Figure 4. Unfortunately at the present time we have no method of determining which one of the solutions shown in this Figure represents the correct two compartment model, but it is evident that any of the possible solutions shown represents a fairly marked degree of uneven DL/Q்c. For instance, if the lung is divided into two compartments with equal amounts of DL, the amount of blood flowing through the compartment with the lesser amount of $\dot{Q} \mathrm{c}$ varied from a low value of $8 \%$ of total Q $\mathrm{Q}$ in subject JC to a high value of $28 \%$ in subject $\mathrm{RR}$. The median value, represented by subject GGP, was $13 \%$. (If no uneven DL/Q்c were present, $\dot{Q} c$ through each compartment would be $50 \%$ of total Q̇c.)

Uneven DL/Q்c showed a tendency to be more marked with increasing age, for in the two subjects over 40 years old $50 \%$ of DL received on the average $9 \%$ of the total $\dot{Q}$, whereas in the three subjects under $40,50 \%$ of DL received $20 \%$ of total $\dot{Q}$ c. Measurements in more subjects over a wider age range would be needed to confirm this suggestion of progressively severe uneven DL/Q́c with advancing age. 
TABLE II

Data for determination of uneven $\mathrm{DL} / \mathrm{Qc}$ in five subjects*

\begin{tabular}{|c|c|c|c|c|c|c|c|c|c|c|c|}
\hline Subject & $\dot{Q} \mathrm{c}$ & Vc & DLcot & Dмco $\ddagger$ & $\mathrm{DM}_{\mathbf{3 4}_{\mathrm{O}_{2}}} \delta$ & $\begin{array}{c}\text { Alveolar } \\
\mathrm{PO}_{2} \|\end{array}$ & $\alpha b_{O_{2}} \pi$ & $\theta \mathrm{O}=2$ & $\begin{array}{l}\text { True } \\
\text { DLO2 }\end{array}$ & $\begin{array}{c}\text { Observed } \\
\mathrm{DLO}_{2}\end{array}$ & $\begin{array}{c}\text { Observed } \\
\text { DLO2 } \\
\text { as per } \\
\text { cent of } \\
\text { true } \\
\text { DLO2 }\end{array}$ \\
\hline & $L / \min$ & $m l$ & $m l$ & $m l$ & $m l$ & $m m \mathrm{Hg}$ & $m l / m l$ & $m l$ & $m l$ & $m l$ & $\%$ \\
\hline . & & & $\overline{\mathrm{min}_{\mathrm{mm} \mathrm{Hg}}}$ & $\overline{\min _{\mathrm{mm} H g}}$ & $\overline{\min _{\mathrm{mm} H g}}$ & & & $\overline{\times \underset{\times m m}{\min } \mathrm{Hg}}$ & $\overline{\min ^{\min } \mathrm{Hg}}$ & $\overline{\min }$ & \\
\hline $\begin{array}{l}\text { RR } \\
\text { GGP } \\
\text { RWH } \\
\text { REF } \\
\text { JC }\end{array}$ & $\begin{array}{l}8.2 \\
8.0 \\
7.1 \\
6.2 \\
6.3\end{array}$ & $\begin{array}{r}98 \\
106 \\
112 \\
80 \\
123\end{array}$ & $\begin{array}{l}44 \\
51 \\
44 \\
40 \\
43\end{array}$ & $\begin{array}{l}59 \\
72 \\
57 \\
53 \\
66\end{array}$ & $\begin{array}{l}70 \\
86 \\
68 \\
63 \\
79\end{array}$ & $\begin{array}{l}36.0 \\
41.5 \\
42.0 \\
49.0 \\
43.5\end{array}$ & $\begin{array}{l}2.49 \\
2.71 \\
2.62 \\
2.60 \\
2.46\end{array}$ & $\begin{array}{l}2.8 \\
2.8 \\
2.7 \\
2.5 \\
2.7\end{array}$ & $\begin{array}{l}56 \\
62 \\
55 \\
48 \\
64\end{array}$ & $\begin{array}{l}46 \\
34 \\
35 \\
23 \\
26\end{array}$ & $\begin{array}{l}82 \\
55 \\
64 \\
48 \\
41\end{array}$ \\
\hline Average & 7.2 & 104 & 44 & 61 & 73 & 42.0 & 2.58 & 2.7 & 57 & 33 & 58 \\
\hline
\end{tabular}

* $\dot{Q}_{c}=$ pulmonary capillary blood flow $; \mathrm{Vc}=$ pulmonary capillary blood volume; DLco and DLo, = carbon monoxide and oxygen diffusing capacity of the lungs; DMCO and DMuо2 = carbon monoxide and oxygen diffusing capacity of the pulmonary membrane; $\mathrm{PO}_{2}=$ oxygen tension; $\alpha \mathrm{b}_{\mathrm{O}_{2}}=$ Bunsen solubility coefficient for total $\mathrm{O}_{2}$ in blood; $\theta \mathrm{O}_{2}=$ diffusing capacity of red blood cells for oxygen.

$\dagger \mathrm{DL}_{\text {co }}$ measured at alveolar $\mathrm{PO}_{2}$ listed in the sixth column of figures. $\mathrm{mm} \stackrel{+}{\mathrm{Hg}}$.

DMco calculated from measurements of DLco performed at alveolar $\mathrm{P}_{\mathrm{O}_{2}}$ of approximately $15 \mathrm{~mm} \mathrm{Hg}$ and 600

\& DM⿻上丨 calculated by multiplying DMco by 1.19 on basis of Graham's law (see text).

II Alveolar $\mathrm{PO}_{2}$ present during the determination of observed $\mathrm{DL}_{\mathrm{O}_{2}}$.

ר $\alpha \mathrm{b}_{\mathrm{O}_{2}}$ and $\mathrm{\theta O}_{2}$ for alveolar $\mathrm{PO}_{2}$ present during determination of observed $\mathrm{DL}_{\mathrm{O}_{2}}$.

\section{Discussion}

The above results indicate that a considerable degree of uneven distribution of diffusing capacity (DL) with respect to pulmonary capillary blood flow ( $\dot{Q} \mathrm{c})$ is present in normal resting human subjects. Among the alternative explanations for the data is the possibility that the DL/Q்c patterns determined are an artifact due to inaccuracies in the measured quantities of either observed $\mathrm{DL}_{\mathrm{O}_{2}}$ or true $\mathrm{DL}_{\mathrm{O}_{2}}$.

Accuracy of observed $\mathrm{DL}_{\mathrm{O}_{2}}$. Sources of error in the measurement of observed $\mathrm{DL}_{\mathrm{O}_{2}}$ have been described in detail elsewhere (5). It was concluded that the error in the measurement is less than $\pm 15 \%$, which is not sufficient to alter dramatically the degree of uneven DL/Q்c calculated for our subjects.

Accuracy of true $\mathrm{DL}_{\mathrm{O}_{2}}$. Appraisal of the accuracy of true $\mathrm{DL}_{\mathrm{O}_{2}}$ is more complex because its value depends on the terms from which it is calculated in Equation 1, namely $\mathrm{Vc}, \mathrm{DM}_{\mathrm{CO}}, \theta \mathrm{O}_{2}$, and the factor 1.19 used to convert $\mathrm{DM}_{\mathrm{CO}}$ into $\mathrm{DM}_{\mathbf{3 4}_{\mathrm{O}_{2}}}$. Errors in the determination of $\mathrm{Vc}$ and $\mathrm{DM}_{\mathrm{CO}}$ by performing $\mathrm{DL}_{\mathrm{CO}}$ at different alveolar $\mathrm{Po}_{2}$ have been discussed previously $(14,18)$. It should be noted that for the subjects in this report errors in $\mathrm{Vc}$ and $\theta \mathrm{O}_{2}$ produce only onethird the error in true $\mathrm{DL}_{\mathrm{O}_{2}}$. Therefore it seems unlikely that those measurements would be sufficiently inaccurate to alter markedly true $\mathrm{DL}_{\mathrm{O}_{2}}$. Errors in DMco, however, produce almost the same per cent change in true $\mathrm{DL}_{\mathrm{O}_{2}}$, but fortunately a lower limit for the value of $\mathrm{DM}_{\mathrm{CO}}$ can be calculated in the following manner: DLCo was measured simultaneously with observed $\mathrm{DL}_{\mathrm{O}_{2}}$. The average value of $D L_{C O}$ for the five subjects was $44 \mathrm{ml}$ per (minute $\times \mathrm{mm} \mathrm{Hg}$ ), which theoretically represents the minimal value possible for $\mathrm{DM}_{\mathrm{CO}}$ under the conditions of the experiment. Even if $\mathrm{DM}_{\mathrm{CO}}$ were this minimal value, the average value for true $\mathrm{DL}_{\mathrm{O}_{2}}$ calculated by Equation 1 would be $43 \mathrm{ml}$ per (minute $\times \mathrm{mm} \mathrm{Hg}$ ), which is still considerably greater than $33 \mathrm{ml}$ per (minute $\times \mathrm{mm} \mathrm{Hg}$ ), the average value of observed $\mathrm{DL}_{\mathrm{O}_{2}}$. The factor 1.19 , used to convert $\mathrm{DM}_{\mathrm{CO}}$ into $\mathrm{DM}_{340_{2}}$, was calculated on the basis of Graham's law and the assumption that the solubilities of $\mathrm{CO}$ and ${ }^{34} \mathrm{O}_{2}$ in the alveolar-capillary membrane are similar to their respective solubilities in water. Though the alveolar-capillary membrane is predominantly water, it contains proteins and lipid membranes that might alter the solubilities of these two gases. Experimentally it has been shown that the relative solubility of $\mathrm{O}_{2}$ of mass 32 compared to $\mathrm{CO}$ is changed from 1.25 to 0.78 if the measurement is made in a solu- 
tion containing equal quantities of glycerol and buffer solution instead of buffer alone (19). If in these experiments the conversion factor used should have been 0.78 instead of 1.19 , the average value of true $\mathrm{DL}_{\mathrm{O}_{2}}$ would fall from $57 \mathrm{ml}$ per (minute $\times \mathrm{mm} \mathrm{Hg}$ ) to $40 \mathrm{ml}$ per (minute $\times \mathrm{mm}$ $\mathrm{Hg})$. This value is still greater than $33 \mathrm{ml}$ per (minute $\times \mathrm{mm} \mathrm{Hg}$ ), the average value of observed $\mathrm{DL}_{\mathrm{O}_{2}}$, so that even if there is an appreciable error in the factor used to convert $\mathrm{DM}_{\mathrm{CO}}$ into $\mathrm{DM}_{\mathrm{O}_{2}}$, there will still be a considerable degree of uneven DL/Q்c in the lungs.

In addition to errors in observed $\mathrm{DL}_{\mathrm{O}_{2}}$ and true $\mathrm{DL}_{\mathrm{O}_{2}}$ several other factors might influence the determination of uneven DL/Q்c, namely the artificiality of constructing a two compartment lung, pulsatile pulmonary capillary blood flow, and the upright posture of the subjects.

Errors arising from the assumption of a two compartment lung. Equation 4 is listed in a form that is applicable to a lung with only two DL/Q்c compartments, but by adding to the denominator inside the large bracket terms of the form, $\dot{\mathrm{Q}} \mathrm{c}_{n} \mathrm{e}^{\left[-\mathrm{DL}_{\mathrm{n}}(760)\right] /\left[\dot{Q}_{\mathrm{n}}\left(\alpha \mathrm{bO}_{2}\right)\right]}$, the equation can be used to construct a lung with many compartments. Although at the present time we have no measurements available that justify the complexity of constructing more than two compartments, it seems likely that the lung may have many capillary pathways with different patterns of DL/Q $\mathbf{c}$ distribution. Although a knowledge of the dimensions of a greater number of compartments would be expected to give a more exact picture, a multicompartment model must still take into account the experimental finding of a large difference between true $\mathrm{DL}_{\mathrm{O}_{2}}$ and observed $\mathrm{DL}_{\mathrm{O}_{2}}$. A multicompartment model of the lungs would therefore not invalidate the existence of uneven DL/Q்c. It would, however, demonstrate the pattern of distribution of uneven DL/Q்c more clearly.

Effect of pulsatile Q̇c on uneven DL/Q்c. Measurements in man of instantaneous Qc indicate that $\dot{Q}_{c}$ is pulsatile (20). If some of the red blood cells rapidly traversed the capillaries during systole, whereas others had a prolonged exposure to the alveolar gas during diastole, variation in DL/Q்c during the cardiac cycle would

TABLE III

Effect of uneven distribution of alveolar volume ( $\mathrm{VA})$, pulmonary capillary blood flow ( $\dot{\mathrm{Q}} \mathrm{c})$, and pulmonary diffusing capacity on measured values of $\mathrm{CO}$ diffusing capacity ( $\left.\mathrm{DL}_{\mathrm{CO}}\right), \mathrm{O}_{2}$ diffusing capacity $\left(\mathrm{DL}_{\mathrm{O}_{2}}\right)$, and the alveolar to end capillary $\mathrm{O}_{2}$ gradient $\left(\mathrm{A}-\mathrm{C} \mathrm{O}_{2} \text { gradient }\right)^{*}$

\begin{tabular}{|c|c|c|c|c|c|c|c|c|c|}
\hline & \multirow{2}{*}{$\begin{array}{c}\text { Com- } \\
\text { part- } \\
\text { ment } \\
\text { no. }\end{array}$} & \multicolumn{5}{|c|}{ Compartment dimensions } & \multirow[b]{2}{*}{$\begin{array}{c}\text { Total } \\
\text { A-c } \mathrm{O}_{2} \\
\text { gradient } \neq\end{array}$} & \multirow[b]{2}{*}{ DLco } & \multirow[b]{2}{*}{$\begin{array}{c}\text { Observed } \\
\text { DL.-2 }\end{array}$} \\
\hline & & $\begin{array}{l}\text { True } \\
\mathrm{DLO}_{2}\end{array}$ & $\dot{\mathrm{Q} c}$ & $\mathrm{~V}_{\mathbf{A}}$ & $\begin{array}{c}\text { Capillary } \\
\text { transit } \\
\text { time }\end{array}$ & $\underset{\text { gradient† }}{\mathrm{A}-\mathrm{C} \mathrm{O}_{2}}$ & & & \\
\hline & & $\frac{m l}{\left(\begin{array}{l}\min X \\
m m H g)\end{array}\right.}$ & $m l / m i n$ & $m l$ & $\sec$ & $m m \mathrm{Hg}$ & $m m \mathrm{Hg}$ & $\frac{m l}{(m i n \times}$ & $\frac{m l}{(\min \times}$ \\
\hline \multirow{3}{*}{$\begin{array}{c}\text { A. Upright posture } \\
\text { (ref. } 1,21)\end{array}$} & 1 & 9.7 & 980 & 1,800 & 1.04 & 0 & & & \\
\hline & 2 & 18.8 & 2,380 & 1,800 & 0.83 & 0 & $\mathbf{0}$ & $\begin{array}{l}41 \\
(-70) 8\end{array}$ & 50 \\
\hline & 3 & 28.5 & 3,840 & 1,800 & 0.78 & 0 & & & \\
\hline \multirow{3}{*}{$\begin{array}{l}\text { B. Anatomical and } \\
\text { microscopic data } \\
\text { (ref. } 7,9,22)\end{array}$} & 1 & 10.0 & 3,600 & T & 0.29 & 0.5 & & & \\
\hline & 2 & 30.0 & 3,600 & I & 0.88 & 0 & 0.25 & 44 & $\begin{array}{c}27.2 \\
(-5 . \%)\end{array}$ \\
\hline & 3 & 17.0 & 0 & T & & 0 & & & \\
\hline \multirow{2}{*}{$\begin{array}{l}\text { C. Pulmonary capil- } \\
\text { lary transit time } \\
\text { of } 0.1 \text { sec in } 5 \% \\
\text { of capillary } \\
\text { channels (ref. 23) }\end{array}$} & 1 & 1.46 & 1,530 & ๆ & 0.10 & 16.5 & & & \\
\hline & 2 & 55.54 & 5,670 & Т & 1.03 & 0 & 5 & $\begin{array}{l}44 \\
(0 \%) 8\end{array}$ & $(-38.1)$ \\
\hline \multirow{2}{*}{$\begin{array}{l}\text { D. Measurements in } \\
\text { anesthetized dogs } \\
\text { (ref. 3) }\end{array}$} & 1 & 1.14 & 1,200 & T & 0.12 & 12 & & & \\
\hline & 2 & 55.86 & 6,000 & ๆ & 0.86 & 0 & 2 & $\begin{array}{l}44 \\
(0 \%) \S\end{array}$ & $\left(-\frac{40.1}{30 \%}\right) \|$ \\
\hline
\end{tabular}

* Representative measurements in our subjects were used, namely, DLO2 calculated from the CO data (true DLo2) $=57 \mathrm{ml}$ per (minute $\times$ mm $\mathrm{Hg}$ ), total $Q_{\mathrm{c}}=7,200 \mathrm{ml}$ per minute, total $\mathrm{VA}_{\mathrm{A}}=5,400 \mathrm{ml}, \mathrm{DL} \cdot \mathrm{co}=44 \mathrm{ml}$ per (minute $\left.\times \mathrm{mm} \mathrm{Hg}\right)$, and capillary blood volume $(\mathrm{Vc})=100 \mathrm{ml}$. $+\mathrm{A}-\mathrm{c} \mathrm{O}_{2}$ gradients were taken from Figure 5 .

¥ The numbers in this column were calculated from the $\mathrm{A}-\mathrm{c} \mathrm{O}_{2}$ gradient of each compartment. Alveolar Po2 was assumed to be $100 \mathrm{~mm} \mathrm{Hg}$, end capillary $\mathrm{O}_{2}$ content for each compartment was obtained from a standard $\mathrm{O}_{2}$ dissociation curve at $\mathrm{pH}$ of 7.40 .

\& Per cent reduction from DLco of $44 \mathrm{ml}$ per (minute $\times \mathrm{mm} \mathrm{Hg}$ ).

Per cent reduction from true $\mathrm{DLO}_{2}$ of $57 \mathrm{ml}$ per (minute $\times \mathrm{mm} \mathrm{Hg}$ ).

I Uneven $\mathrm{DL} / \dot{Q}_{\mathrm{c}}$ was considered to be within each gas exchange unit so that all alveoli had the same rate of change of $\mathrm{CO}$ and ${ }^{4} \mathrm{O}_{2}$ during breath holding. 
result (2). Because this form of uneven DL/Q்c might explain the difference between observed $\mathrm{DL}_{\mathrm{O}_{2}}$ and true $\mathrm{DL}_{\mathrm{O}_{2}}$ seen in our subjects, we evaluated this possibility by obtaining representative values of pulsatile flow from the data published by Linderholm, Kimbel, Lewis, and DuBois (20) and then calculated an observed $\mathrm{DL}_{\mathrm{O}_{2}}$. We used the values of total $\dot{Q} \mathrm{c}, \mathrm{Vc}$, and true $\mathrm{DL}_{\mathrm{O}_{2}}$ listed in Table III, a pulse rate of 100 per minute, a systole of 0.12 second with a $\dot{Q} c$ of $300 \mathrm{ml}$ per second, and diastole of 0.48 second with a $\dot{Q} c$ of $75 \mathrm{ml}$ per second. No significant change in $\mathrm{DL}_{\mathrm{O}_{2}}$ was produced by this pattern of Q́c, but if pulsatile blood flow were combined with uneven DL/Q்c such as illustrated in Figures $1 \mathrm{~B}$ and $1 \mathrm{C}$, rapid pulsatile flow through capillaries of short length would permit some blood to pass through them during systole and thereby produce a very brief exposure to alveolar gas. Such a condition would decrease observed $\mathrm{DL}_{\mathrm{O}_{2}}$ without changing true $\mathrm{DL}_{\mathrm{O}_{2}}$. At the present time we have no method of separating uneven DL/Q்c due to pulsatile flow from uneven DL/Q்c from other causes, so that pulsatile flow may be a significant contributing factor to the uneven DL/Q்c observed in our subjects.

Effect of uneven perfusion and diffusion per unit of lung volume secondary to the upright position. Evidence has been presented that in the upright posture the upper zones of the lungs have considerably less Q́c and DL per unit of lung volume (VA) than is found in the lower zones $(21,24)$. To establish whether this type of uneven distribution might explain our data, we calculated the changes in $\mathrm{DL}_{\mathrm{O}_{2}}$ and $\mathrm{DL}_{\mathrm{CO}}$ that would result in a subject whose lungs had three zones of equal VA, but proportionately less amounts of DL and $\dot{Q} c$ in the upper zones. Numerical values for total $\mathrm{VA}_{\mathrm{A}}, \mathrm{DL}$, and $\dot{Q}_{\mathrm{c}}$ are representative for our subjects, and the dimensions of the three zones were chosen on the basis of observations made by others using regional scanning of the lungs after the inspiration of radioactive $\mathrm{CO}$ and $\mathrm{CO}_{2}(1,21)$ (see Table III). This model of uneven distribution produced a decrease in $\mathrm{DL}_{\mathrm{O}_{2}}$ of $12 \%$ and a decrease in Dico of $7 \%$. Since these changes in part cancel out during the determination of uneven DL/Q்c and also are too small to account for the $18 \%$ to $64 \%$ difference between observed $\mathrm{DL}_{\mathrm{O}_{2}}$ and true $\mathrm{DL}_{\mathrm{O}_{2}}$ seen in our subjects, we do not think the sitting position alone explains the uneven DL/Q்c we calculated.

In addition, the effect of uneven distribution of alveolar volume (VA) with respect to DL (uneven $\mathrm{VA} / \mathrm{DL}$ ) resulting from the upright position was evaluated with compartmental dimensions based on the data reported by Burrows and co-workers (25). These calculations showed that there would be changes in $\mathrm{DL}_{\mathrm{O}_{2}}$ and $\mathrm{DL}_{\mathrm{CO}}$ but insufficient in magnitude or direction to produce significant changes in the calculated values of uneven DL/Q். We conclude that uneven distribution of DL with respect to $\dot{Q}_{c}$ within each gas exchange unit of the lung is the best explanation for our experimental findings. Although it is likely that there is uneven distribution of DL/Q்c and DL/VA in gross anatomical zones of the lung, the value of observed $\mathrm{DL}_{\mathrm{O}_{2}}$ would be only slightly reduced. The comparison of observed $\mathrm{DL}_{\mathrm{O}_{2}}$ to true $\mathrm{DL}_{\mathrm{O}_{2}}$ is, therefore, not a good method for investigating this particular type of uneven distribution.

Comparison to other measurements of uneven DL/Q́c. Piiper, Haab, and Rahn calculated the degree of uneven DL/Q $\mathrm{Q}$ in anesthetized dogs from measurements of the alveolar-arterial $\mathrm{O}_{2}$ gradient (3). They concluded that diffusion of $\mathrm{O}_{2}$ in to the blood takes place from two functional compartments, namely one small compartment containing $2 \%$ of the diffusing capacity and receiving $14 \%$ of total Q்c and one large compartment containing $98 \%$ of the diffusing capacity and receiving $86 \%$ of $\dot{Q} \mathrm{c} .{ }^{6}$ If there were a similar pattern of uneven DL/Q்c in the lungs of our human subjects, it would have no influence on the value of $\mathrm{DL}_{\mathrm{CO}}$, but $\mathrm{DL}_{\mathrm{O}_{2}}$ would decrease from its average "true" value of $57 \mathrm{ml}$ per (minute $\times \mathrm{mm} \mathrm{Hg})$ to an observed $\mathrm{DL}_{\mathrm{O}_{2}}$ of $40.1 \mathrm{ml}$ per (minute $X \mathrm{~mm} \mathrm{Hg}$ ), which is slightly greater then the experimentally determined average value of $33 \mathrm{ml}$ per (minute $\times \mathrm{mm} \mathrm{Hg}$ ). Preliminary studies in resting man using breath holding with $5 \%$ carbon monoxide (26) and the steady state $\mathrm{O}_{2}$ diffusing capacity method (27)

${ }^{6}$ These authors reported that a small portion of the perfusion $(1.5 \%)$ probably behaves like a true shunt $(\mathrm{DL} / \dot{\mathrm{Q}} \mathrm{c}=0)$. This compartment was omitted in our analysis because the method of measuring uneven DL/Q்c described in this paper is only influenced by perfusion that comes in contact with alveolar $\mathrm{CO}$, acetylene, and ${ }^{34} \mathrm{O}_{2}$ during the breath-holding maneuver. 
indicate that two-thirds of $\dot{Q} c$ is delivered to $20 \%$ of the diffusing capacity. In the subjects of the present study this pattern of uneven $\mathrm{DL} / \dot{Q} \mathrm{c}$ would result in an observed $\mathrm{DL}_{\mathrm{O}_{2}}$ of approximately $30 \mathrm{ml}$ per (minute $\times \mathrm{mm} \mathrm{Hg}$ ) (see Figure 3), which is in good agreement with the experimentally determined average value of $33 \mathrm{ml}$ per (minute $\times \mathrm{mm} \mathrm{Hg}$ ).

Influence of uneven $\mathrm{DL} / \dot{Q} \mathrm{c}$ on the pulmonary alveolar to end capillary $\mathrm{O}_{2}$ gradient (A-c $\mathrm{O}_{2}$ gradient). The presence of uneven $\mathrm{DL} / \dot{\mathrm{Q}} \mathrm{c}$ within the alveoli of the lungs has considerable bearing on the estimation of the size of the A-c $\mathrm{O}_{2}$ gradient. Previous reports do not agree about the magnitude of this gradient in normal individuals or even in diseased subjects. On the basis of measurements of distribution of ventilation to perfusion, right to left shunting around the alveoli, and the single breath DLco, some authors have stated that even in the so-called alveolar-capillary block syndrome an A-c $\mathrm{O}_{2}$ gradient does not exist $(28,29)$. On the other hand, more recently Johnson, Taylor, and DeGraff have cited evidence showing that the arterial $\mathrm{O}_{2}$ desaturation seen in certain diffuse restrictive diseases of the lung tissues may in part be explained by an A-c $\mathrm{O}_{2}$ gradient produced by the presence of red blood cell transit times of different duration in the pulmonary capillary bed (30). After a careful analysis of the influence of both uneven DL/Q்c and uneven ventilation-perfusion ratios upon the A-c $\mathrm{O}_{2}$ gradient, Piiper and co-workers concluded that the $\mathrm{O}_{2}$ gradient they measured in anesthetized dogs was principally due to uneven $\mathrm{DL} / \dot{\mathrm{Q}} \mathrm{c}$ rather than uneven ventilation-perfusion ratios (3).

Because we have no data that permit the determination of the precise pattern of uneven DL/Q்c present in the lungs of our subjects, its exact contribution to the A-c $\mathrm{O}_{2}$ gradient cannot be calculated at the present time. As an alternative we chose four patterns of uneven DL/Q் fashioned after reports in the literature and calculated the $\mathrm{A}-\mathrm{c} \mathrm{O}_{2}$ gradient that would result in a resting subject with values for true $\mathrm{DL}_{\mathrm{O}_{2}}$, Q $\mathrm{c}$, and Vc approximately the same as found in our subjects (see Table III). Using these values together with a mixed venous $\mathrm{Po}_{2}$ of $42.5 \mathrm{~mm} \mathrm{Hg}$ and an alveolar $\mathrm{Po}_{2}$ of $100 \mathrm{~mm} \mathrm{Hg}$, one can calculate the rate at which the $\mathrm{Po}_{2}$ in the red blood

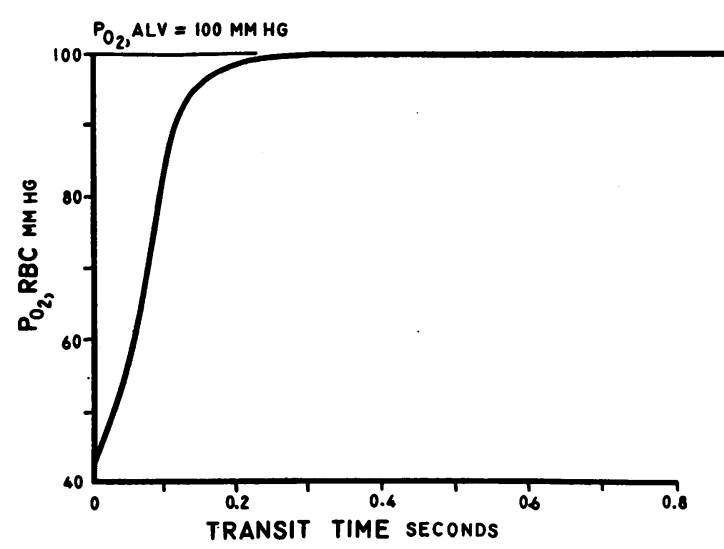

Fig. 5. RATE OF RISE OF $\mathrm{PO}_{2}$ IN A RED BLOOD CELL AS IT TRAVERSES A CAPILLARY IN THE LUNGS OF A SUBJECT With A MIXEd venous $\mathrm{PO}_{2}$ OF 42.5 MM Hg ANd AN ALveOLAR $\mathrm{PO}_{2}$ OF $100 \mathrm{MM} \mathrm{Hg}$. Oxygen diffusing capacity of the membrane was considered to be $73 \mathrm{ml}$ per (minute $\times \mathrm{mm}$ $\mathrm{Hg}$ ) and $\mathrm{Vc} 100 \mathrm{ml}$, which are representative values for our subjects. [For details of the calculation see (12)]. $\mathrm{Po}_{2}$, RBC is the $\mathrm{Po}_{2}$ in the capillary blood for any particular transit time. Note that when the capillary transit time falls below 0.2 second, a significant alveolar to end capillary $\mathrm{O}_{2}$ gradient develops.

cells increases as they traverse the capillaries (12). This calculation is presented graphically in Figure 5, and from it we determined the end capillary $\mathrm{PO}_{2}$ for a $\mathrm{DL} / \dot{Q} c$ compartment whose capillary transit time $\left(\mathrm{TL}_{\mathrm{L}}\right)$ is known. ${ }^{7}$

A-c $\mathrm{O}_{2}$ gradient secondary to the upright posture. Table IIIA shows the effect of uneven DL/Q்c and uneven $\mathrm{VA}_{\mathrm{A}} / \dot{\mathrm{Q}} \mathrm{c}$ secondary to the upright posture on the A-c $\mathrm{O}_{2}$ gradient. Because the shortest $T_{L}$ for this model is 0.78 second, essentially no A-c $\mathrm{O}_{2}$ gradient is present.

$\mathrm{A}-\mathrm{c} \mathrm{O}_{2}$ gradient secondary to the $\mathrm{DL} / \mathrm{Q} \mathrm{c}$ distribution observed in microscopic studies of the pulmonary capillary bed. Von Hayek (9) and Weibel (22) have pointed out that the capillary pathway from the pulmonary arterioles to the pulmonary veins is a meshwork of vessels whose length may

${ }^{7}$ Calculation of end capillary $\mathrm{Po}_{2}$ from Figure 5 requires the assumption of even distribution of $\mathrm{Vc}$ with respect to membrane diffusing capacity (vide supra). Once this assumption is accepted, the per cent of the membrane diffusing capacity of a compartment equals the same percentage of total Vc. $T_{L}$ of the compartment can then be calculated by the following relationship: $T_{L}=V c$ of compartment/ Qc of compartment. If $\mathrm{Vc}$ is not distributed evenly with respect to membrane diffusing capacity, the end capillary $\mathrm{Po}_{2}$ can still be calculated, but the procedure becomes more laborious. 
vary from about $60 \mu$ to $250 \mu$ or longer. It has been postulated from in vivo observations that shorter routes stay open whereas longer ones may be intermittently closed off. Blood flow in some capillaries has been seen to stop and even reverse direction (7). On the basis of the above information we constructed a lung model in which, in each gas exchange unit, $50 \%$ of the blood flow goes through capillaries $80 \mu$ long, and the other $50 \%$ traverses capillaries $240 \mu$ long. In addition, $30 \%$ of the capillary blood volume contains blood that is not flowing (see Table IIIB). Although this pattern of uneven DL/Q்c according to Equation 4 would produce an observed $\mathrm{DL}_{\mathrm{O}_{2}}$ of $27 \mathrm{ml}$ per (minute $\times \mathrm{mm}$ $\mathrm{Hg}$ ) compared to the true $\mathrm{DL}_{\mathrm{O}_{2}}$ of $57 \mathrm{ml}$ per (minute $\times \mathrm{mm} \mathrm{Hg}$ ) (values similar to those seen in our subjects, the A-c $\mathrm{O}_{2}$ gradient is barely perceptible $(0.25 \mathrm{~mm} \mathrm{Hg})$.

$\mathrm{A}-\mathrm{c} \mathrm{O}_{2}$ gradient secondary to the uneven $\mathrm{DL} / \dot{\mathrm{Q}} \mathrm{c}$ suggested by cinematographic observations of the pulmonary capillary bed in vivo. Schlosser, Heyse, and Bartels recently developed a method that permits the visualization of the subpleural pulmonary capillaries of rabbit lungs. They reported that the average transit time for a red blood cell through these capillaries is only 0.1 second (23). On the basis of their observations we calculated the observed $\mathrm{DL}_{\mathrm{O}_{2}}$ and $\mathrm{A}-\mathrm{C} \mathrm{O}_{2}$ gradient that would result if $5 \%$ of the capillary channels carrying blood from the pulmonary arteries to the pulmonary veins were $60 \mu$ long and had a transit time of 0.1 second. The remaining $95 \%$ of the channels were assumed to be $120 \mu$ long and would receive $79 \%$ of the total blood flow (see Table IIIC). According to Equation 4 this pattern of uneven $\mathrm{DL} / \mathrm{Q}_{\mathrm{c}}$ results in an observed $\mathrm{DL}_{\mathrm{O}_{2}}$ of $38 \mathrm{ml}$ per (minute $\times \mathrm{mm} \mathrm{Hg}$ ), a value $33 \%$ less than the true $\mathrm{DL}_{\mathrm{O}_{2}}$ of $57 \mathrm{ml}$ per (minute $\times \mathrm{mm} \mathrm{Hg}$ ). In the fast compartment the A-c $\mathrm{O}_{2}$ gradient would be $16.5 \mathrm{~mm} \mathrm{Hg}$, and after mixing with the blood from the slow compartment, the total pulmonary A-c $\mathrm{O}_{2}$ gradient would be $5 \mathrm{~mm} \mathrm{Hg}$. These data suggest that a significant amount of the difference between alveolar and arterial $\mathrm{Po}_{2}$ could be due to uneven DL/Q்c.

A-c gradient secondary to the pattern of uneven DL/Q்c observed in anesthetized dogs. Piiper and co-workers concluded that in anesthetized dogs diffusion of $\mathrm{O}_{2}$ in the pulmonary capillary blood takes place from two functional compartments, a smaller one receiving $14 \%$ of $\dot{Q} c$, but containing only $2 \%$ of the diffusing capacity, and a larger compartment with $86 \%$ of $\dot{Q} \mathrm{c}$ and $98 \%$ of the diffusing capacity (vide supra). For our human subjects the A-c $\mathrm{O}_{2}$ gradient for the smaller compartment according to Figure 5 would be $12 \mathrm{~mm}$ $\mathrm{Hg}$ and after mixing with the blood flowing through the larger compartment would decrease to $2 \mathrm{~mm} \mathrm{Hg}$. The comparable figure for the A-c $\mathrm{O}_{2}$ gradient from both compartments calculated by Piiper and co-workers was $10 \mathrm{~mm} \mathrm{Hg}$. This discrepancy can be accounted for by a number of factors, including the larger value of $\mathrm{DL}_{\mathrm{O}_{2}}$ in the human subjects $[0.8 \mathrm{ml}$ per (minute $\times \mathrm{mm} \mathrm{Hg}$ ) per kg vs. $0.3 \mathrm{ml}$ per (minute $\times \mathrm{mm}$ $\mathrm{Hg}$ ) per $\mathrm{kg}$ in dogs]; the difference in the $\mathrm{O}_{2}$ dissociation curves used, which is quite critical in the calculation of the A-c $\mathrm{O}_{2}$ gradient (31); and the fact that the fall in $\mathrm{DL}_{\mathrm{O}_{2}}$ with rising intracapillary $\mathrm{O}_{2}$ recently demonstrated in vivo (5) was taken into account in the humans but not in the dogs.

Relationship between $\mathrm{DL}$ and the size of the A-c $\mathrm{O}_{2}$ gradient. The data in Table III demonstrate an apparent paradox: A lung model such as IIIB may have a lower observed $\mathrm{DL}_{\mathrm{O}_{2}}$ than another model, yet its $\mathrm{A}-\mathrm{c} \mathrm{O}_{2}$ gradient may be smaller. Therefore the observed values of $\mathrm{DL}_{\mathrm{O}_{2}}$ and DLCo in the presence of uneven DL/Q்c do not necessarily give information relevant to the estimation of the size of the A-c $\mathrm{O}_{2}$ gradient. The precise pattern of distribution of uneven DL/Q்c may be of greater importance in determining this gradient than the absolute values of diffusing capacity. For example, in the four hypothetical lungs listed in Table III, the A-C $\mathrm{O}_{2}$ gradient varied from essentially 0 to $5 \mathrm{~mm}$ $\mathrm{Hg}$ depending more on the pattern of uneven $\mathrm{DL} / \dot{\mathrm{Q}} \mathrm{c}$ chosen than on the measured values of DLCO or $\mathrm{DL}_{\mathrm{O}_{2}}$.

It has been stated that in normal subjects breathing air at rest or even during heavy exercise, as well as in patients with chronic airway obstruction, no A-c $\mathrm{O}_{2}$ gradient will be present because of the large size of the diffusing capacity $(12,28,32)$. All of these calculations have assumed even distribution of diffusing capacity to blood flow. The data presented in this report indicate that fairly marked degrees of uneven $\mathrm{DL} / \dot{\mathrm{Q}} \mathrm{c}$ may be present in resting man, and it is 
possible for this uneven DL/Q்c to be distributed in a manner that produces an appreciable $\mathrm{A}-\mathrm{c} \mathrm{O}_{2}$ gradient. In the face of this information we believe it is hazardous to judge the size of the A-C $\mathrm{O}_{2}$ gradient on the basis of $\mathrm{CO}$ diffusing capacities alone. The distribution of diffusing capacity with respect to $\dot{Q} c$ must be taken in to account.

Although our results do not permit the calculation of the $\mathrm{A}-\mathrm{c} \mathrm{O}_{2}$ gradient, they do suggest that the development of more precise methods for the measurement of the pattern of uneven DL/Q்c may permit an accurate estimation of its size.

\section{Appendix}

Derivation of Equation 4 in the text, which expresses observed $\mathrm{DL}_{\mathrm{O}_{2}}$ as a function of the distribution of diffusing capacity (DL) with respect to pulmonary capillary blood flow (Q்) in the lung.

The total ${ }^{34} \mathrm{O}_{2}$ leaving the lungs per minute during breath holding equals the amount leaving via the pulmonary capillaries less the amount arriving in the mixed venous blood, or:

total ${ }^{34} \mathrm{O}_{2}$ leaving lungs per minute in milliliters per

$$
\text { minute }=\frac{\dot{Q} \mathrm{c}\left(\alpha \mathrm{b}_{\mathrm{O}_{2}}\right)\left(\mathrm{Pc}_{34 \mathrm{O}_{2}}-\mathrm{Pmv}_{{ }_{34} \mathrm{O}_{2}}\right)}{760}
$$

where $\dot{Q} c$ is expressed in milliliters per minute, $\mathrm{Pc}_{34} \mathrm{O}_{2}$ equals the end capillary $\mathrm{P}^{34} \mathrm{O}_{2}$ in millimeters $\mathrm{Hg}, \mathrm{Pmv}_{34} \mathrm{O}_{2}$ is the mixed venous $\mathrm{P}^{34} \mathrm{O}_{2}$ in millimeters $\mathrm{Hg}$, and $\alpha \mathrm{b}_{2}$ is the Bunsen solubility coefficient for total $\mathrm{O}_{2}$ in the blood in milliliters per milliliter per standard atmosphere calculated from the capillary $\mathrm{Po}_{2}$ present during breath holding and the $\mathrm{O}_{2}$ capacity of the subject's blood.

If a lung with uneven DL/Q்c could be divided into compartments within which diffusing capacity and $\dot{Q} c$ were distributed evenly, then as in Equation 2:

$$
\begin{aligned}
\mathrm{DL}_{1}= & \frac{\dot{\mathrm{Q}} \mathrm{c}_{1}\left(\alpha \mathrm{b}_{\mathrm{O}_{2}}\right)}{760} \ln \left(\frac{1}{\mathrm{~K}_{1}}\right) \\
& \mathrm{DL}_{2}=\frac{\dot{\mathrm{Q}} \mathrm{c}_{2}\left(\alpha \mathrm{b}_{\mathrm{O}_{2}}\right)}{760} \ln \left(\frac{1}{\mathrm{~K}_{2}}\right), \quad \mathrm{DL}_{3}=\ldots \text { etc., }
\end{aligned}
$$

where $\mathrm{DL}_{1}, \mathrm{DL}_{2}, \mathrm{DL}_{3} \ldots, \dot{\mathrm{Q}} \mathrm{c}_{1}, \dot{\mathrm{Q}} \mathrm{c}_{2} \ldots$. , and $\mathrm{K}_{1}$, $\mathrm{K}_{2} \ldots$, are, respectively, the true $\mathrm{DL}_{\mathrm{O}_{2}}, \dot{\mathrm{Q}} \mathrm{c}$, and $\mathrm{K}$ for each compartment. The amount of ${ }^{34} \mathrm{O}_{2}$ removed from each compartment per minute can be calculated by applying Equation 5, and for example for compartment 1 would equal:

$$
\frac{\dot{Q} c_{1}\left(\alpha b_{O_{2}}\right)\left({ }^{1} \mathrm{Pc}_{34 \mathrm{O}_{2}}-\mathrm{Pmv} \mathrm{mi}_{2}\right)}{760}
$$

where ${ }^{1} \mathrm{Pc}_{34} \mathrm{O}_{2}$ equals the end capillary $\mathrm{P}^{34} \mathrm{O}_{2}$ in compartment 1.

For a two compartment lung the total milliliters of ${ }^{34} \mathrm{O}_{2}$ leaving the lung per minute during breath holding must equal the sum of the amount leaving the two compartments in the blood less the amount entering, or:

$$
\begin{aligned}
& \frac{\dot{Q} c\left(\alpha \mathrm{b}_{\mathrm{O}_{2}}\right)\left(\mathrm{Pc}_{34} \mathrm{O}_{2}-\mathrm{Pmv}_{3_{4} \mathrm{O}_{2}}\right)}{760} \\
& =\frac{\dot{Q} c_{1}\left(\alpha b_{\mathrm{O}_{2}}\right)\left({ }^{1} \mathrm{Pc}_{34 \mathrm{O}_{2}}-\mathrm{Pmv}_{34} \mathrm{O}_{2}\right)}{760} \\
& +\frac{\dot{Q} c_{2}\left(\alpha b_{\mathrm{O}_{2}}\right)\left({ }^{2} \mathrm{Pc}_{34} \mathrm{O}_{2}-\mathrm{Pmv}_{34} \mathrm{O}_{2}\right)}{760} \text {. }
\end{aligned}
$$

$\mathrm{K}$ for a compartment of the lung can be defined as in Equation 3 and for compartment 1 would be :

$$
\mathrm{K}_{1}=\frac{\left(\text { alveolar } \mathrm{P}^{34} \mathrm{O}_{2}-{ }^{1} \mathrm{Pc}_{34 \mathrm{O}_{2}}\right)}{\left(\text { alveolar } \mathrm{P}^{34} \mathrm{O}_{2}-\mathrm{Pmv}_{34} \mathrm{O}_{2}\right)} \text {. }
$$

The terms $\mathrm{Pc}_{34} \mathrm{O}_{2},{ }^{1} \mathrm{Pc}_{34} \mathrm{O}_{2}$, and ${ }^{2} \mathrm{Pc}_{34} \mathrm{O}_{2}$ can be eliminated from Equation 8 by substituting in their respective values obtained from Equations 3 and 9. The resultant equation simplifies to the following form:

$$
\frac{1}{\mathrm{~K}}=\frac{\dot{\mathrm{Q}} \mathrm{c}}{\dot{\mathrm{Q}} \mathrm{c}_{1}\left(\mathrm{~K}_{1}\right)+\dot{\mathrm{Q}} \mathrm{c}_{2}\left(\mathrm{~K}_{2}\right)} \text {. }
$$

Equation 6 can be solved for $K_{1}$ and $K_{2}$ and then substituted into Equation 10, giving:

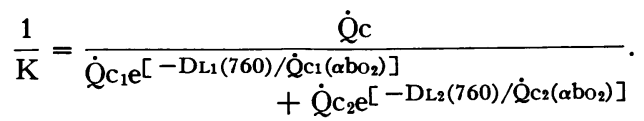

Equation 9 can be substituted into Equation 2 so as to eliminate $1 / \mathrm{K}$ giving :

$$
\begin{aligned}
& \text { observed } \mathrm{DL}_{\mathrm{O}_{2}}=\frac{\dot{\mathrm{Q}} \mathrm{c}\left(\alpha \mathrm{b}_{\mathrm{O}_{:}}\right)}{760}
\end{aligned}
$$

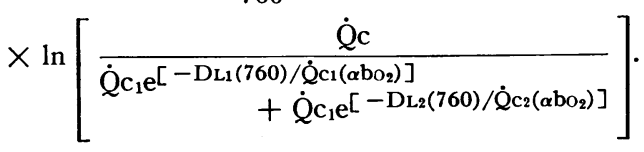

\section{Acknowledgment}

The authors wish to express their appreciation to Dr. Robert E. Forster for his interest and advice.

\section{Addendum}

While this paper was in press, we obtained an article by Thews and Witte (33), in which they included a theoretical analysis of the influence of nonuniform distribution of $\mathrm{O}_{2}$ diffusion on the alveolar to end capillary $\mathrm{O}_{2}$ gradient. Their calculations showed that if distribution of $\mathrm{O}_{2}$ diffusing capacity is nonhomogeneous, the "apparent" $\mathrm{O}_{2}$ diffusing capacity will always be less than the "true" $\mathrm{O}_{2}$ diffusing capacity, and the end capillary $\mathrm{O}_{2}$ tens: on will be lower than if diffusing capacity were uniformly distributed. Their findings, which are in agreement with ours, indicate that the steady state $\mathrm{O}_{2}$ diffusing capacity is affected by uneven DL/Q்c in a manner similar to that described in this report for the single breath $\mathrm{O}_{2}$ diffusing capacity.

\section{References}

1. Dollery, C. T., N. A. Dyson, and J. D. Sinclair. Regional variations in uptake of radioactive $\mathrm{CO}$ in the normal lung. J. appl. Physiol. 1960, 15, 411. 
2. Piiper, J. Unequal distribution of pulmonary diffusing capacity and the alveolar-arterial $\mathrm{Po}_{2}$ differences: theory. J. appl. Physiol. 1961, 16, 493.

3. Piiper, J., P. Haab, and H. Rahn. Unequal distribution of pulmonary diffusing capacity in the anesthetized dog. J. appl. Physiol. 1961, 16, 499.

4. Piiper, J. Variations of ventilation and diffusing capacity to perfusion determining the alveolararterial $\mathrm{O}_{2}$ difference: theory. J. appl. Phsyiol. $1961,16,507$.

5. Hyde, R. W., R. E. Forster, G. G. Power, J. Nairn, and R. Rynes. Measurement of $\mathrm{O}_{2}$ diffusing capacity of the lungs with a stable $\mathrm{O}_{2}$ isotope. J. clin. Invest. 1966, 45, 1178.

6. Lilienthal, J. L., Jr., R. L. Riley, D. D. Proemmel, and R. E. Franke. An experimental analysis in man of the oxygen pressure gradient from alveolar air to arterial blood during rest and exercise at sea level and at altitude. Amer. J. Physiol. 1946, 147, 199.

7. Wearn, J. T., A. C. Ernstene, A. W. Bromer, J. S. Barr, W. J. German, and L. J. Zschiesche. The normal behavior of the pulmonary blood vessels with observations on the intermittence of the flow of blood in the arterioles and capillaries. Amer. J. Physiol. 1934, 109, 236.

8. Miller, W. S. The Lung, 2nd ed. Springfield, Ill., Charles C Thomas, 1947, pp. 74-77.

9. Von Hayek, H. The Human Lung, V. E. Krahl, Trans. New York, Hafner, 1960, p. 253.

10. Sackner, M. A., K. A. Feisal, and D. N. Karsch. Size of gas exchange vessels in the lung. J. clin. Invest. 1964, 43, 1847.

11. Rossier, P. H., A. A. Buhlmann, and K. Wiesinger. Respiration: Physiologic Principles and Their Clinical Applications, P. C. Luchsinger and K. M. Moser, Trans. St. Louis, C. V. Mosby, 1960, pp. 89-93.

12. Staub, N. C. Alveolar-arterial oxygen tension gradient due to diffusion. J. appl. Physiol. 1963, 18, 673 .

13. Roughton, F. J. W. Transport of oxygen and carbon dioxide in Handbook of Physiology, Section 3, Respiration, W. O. Fenn and H. Rahn, Eds. Washington, D. C., American Physiological Society, 1964 , vol. 1, p. 781.

14. Roughton, F. J. W., and R. E. Forster. Relative importance of diffusion and chemical reaction rates in determining rate of exchange of gases in the human lung, with special reference to true diffusing capacity of pulmonary membrane and volume of blood in the lung capillaries. J. appl. Physiol. 1957, 11, 290.

15. Staub, N. C., J. M. Bishop, and R. E. Forster. Importance of diffusion and chemical reaction rates in $\mathrm{O}_{2}$ uptake in the lung. J. appl. Physiol. 1962, 17, 21.

16. Cander, L., and R. E. Forster. Determination of pulmonary parenchymal tissue volume and pulmonary capillary blood flow in man. J. appl. Physiol. 1959, 14, 541.

17. Bates, D. V., and R. V. Christie. Respiratory Func- tion in Disease. Philadelphia, W. B. Saunders, 1964, p. 92.

18. Krumholz, Richard A. Pulmonary membrane diffusing capacity and pulmonary capillary blood volume: an appraisal of their clinical usefulness. Amer. Rev. resp. Dis. 1966, 94, 195.

19. Ackerman, E., and R. L. Berger. Reaction of oxyhemoglobin with carbon monoxide. Biophys. J. $1963,3,493$.

20. Linderholm, H., P. Kimbel, D. H. Lewis, and A. B. DuBois. Pulmonary capillary blood flow during cardiac catheterization. J. appl. Physiol. 1962, 17,135 .

21. West, J. B. Regional differences in gas exchange in the lung of erect man. J. appl. Physiol. 1962, 17, 893.

22. Weibel, E. R. Morphometrics of the Lung in Handbook of Physiology, Section 3, Respiration, W. O. Fenn and H. Rahn, Eds. Washington, D. C., American Physiological Society, 1964, vol. 1, p. 285.

23. Schlosser, D., E. Heyse, and H. Bartels. Flow rate of erythrocytes in the capillaries of the lung. J. appl. Physiol. 1965, 20, 110.

24. Bryan, A. C., L. G. Bentivoglio, F. Beerel, H. MacLeish, A. Zidulka, and D. Bates. Factors affecting regional distribution of ventilation and perfusion in the lung. J. appl. Physiol. 1964, 19, 395.

25. Burrows, B., A. H. Niden, C. Mittman, R. C. Talley, and W. R. Barclay. Non-uniform pulmonary diffusion as demonstrated by the carbon monoxide equilibration technique: experimental results in man. J. clin. Invest. 1960, 39, 943.

26. Hyde, R. W., R. E. Forster, J. Nairn, G. G. Power, and R. Rynes. Distribution of pulmonary diffusing capacity (DL) in relation to pulmonary capillary blood flow (Q்) (abstract). Physiologist 1965, 8, 199.

27. Miller, J. M., and R. L. Johnson, Jr. Effect of nonuniform blood flow on oxygen diffusing capacity (abstract). Physiologist 1965, 8, 235.

28. Finley, T. N., E. W. Swenson, and J. H. Comroe, Jr. The cause of arterial hypoxemia at rest in patients with "alveolar-capillary block syndrome." J. clin. Invest. 1962, 41, 618.

29. Hamer, J. Cause of low arterial oxygen saturation in pulmonary fibrosis. Thorax 1964, 19, 507.

30. Johnson, R. L., Jr., H. F. Taylor, and A. C. DeGraff, Jr. Functional significance of a low pulmonary diffusing capacity for carbon monoxide. J. clin. Invest. 1965, 44, 789.

31. Haab, P. E., J. Piiper, and H. Rahn. Simple method for rapid determination of an $\mathrm{O}_{2}$ dissociation curve of the blood. J. appl. Physiol. 1960, 15, 1148.

32. Ayres, S. M., and S. Giannelli, Jr. Causes of arterial hypoxemia in patients with obstructive pulmonary emphysema. Amer. J. Med. 1965, 39, 422.

33. Thews, von G., and K. Witte. Der Einfluss statistisch verteilter ungleicher $\mathrm{O}_{2}$-Diffusionswiderstände der Lungenmembran auf die $\mathrm{O}_{2}$-Diffusionskapazität. Beitr. Silikose-Forsch. 1963, 5, 329. 